\title{
C -316
}

\section{STRUCTURES OF ORGANIC, ORGANOMETALLIC AND COORDINATION COMPOUNDS}

09.5-2 FLUORESCENT COPPER(I) CLUSTER SYSTEMS. By N. P. Rath, J. Jasinski and E. M. Holt, Department of Chemistry, Oklahoma State University, Stilliwater, Oklahoma, USA 74073

Temperature dependent fluorescence has been previously observed for copper(I) halide clusters of the format, (CuXL) ${ }_{4}$ where $\mathrm{L}$ is an electron pair donating ligand such as phosphine, amine, nitrile or carboxylate. These tetrameric clusters show $\mathrm{Cu}$ and $\mathrm{I}$ atoms at alternate corners of a distorted cube with each copper atom completing its tetrahedral geometry by electron pair donation from a Tigand.

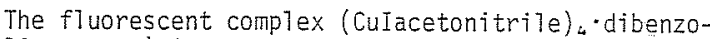
18-crown-6) is of this format with the crown ether a1tering the donicity of the acetonitrile group via a second sphere interaction. The fTuorescent mixed ligand cluster $\left[\left(\mathrm{Cu}_{2} \mathrm{I}_{2}\left(\mathrm{CH}_{3} \mathrm{CN}\right)(\mathrm{p} \text {-ch } 7 \text { roanj Tine })\right]_{2}\right.$ also displays this cubic cluster geometry with copper atoms on one face ligated to acetonitrile groups and those of the opposite face coordinating to the arine nitrogens of p-chloroaniline groups.

However the parent complex of CuI and acetonitrile is of formulation (CuIacetonitrile) $x$, displaying folded sheet structure with distorted squares of alternating $C u$ and $I$ atoms linked together in linear array. Each copper atom has a further Tigation to one acetonitrile nitrogen atom. Fluorescence has not previously been associated with structures of this type.

Details of cluster geometry such as bond lengths, nonbonded metal-metal distances, and symmetry elements present or absent in the cluster may be correlated with the observed temperature dependence of the fluorescence.

09. 5-3 CRYSTAL STRUCTURES OF RUTHENTUM CLUSTER ANIONS AND OSMIUM-BASED MEXED METAL CLUSTERS. By Leh-Yeh Hsu, Ven-liang Hsu, and Sheldon G. Shore, Department of Chemistry, Onio State University, Columbus, Ohio 43210 , U.S.A.

Transition metal clusters have been explored because of their unique types of bonding and because of their potential importance to catalytic chemistry such as hydroformylation and Fischer-Tropsch reactions. Al though spectroscopic elucidation of the cluster structures are useful, $\mathrm{X}$-ray diffraction has proved to be the most rewarding technique in the determination of their molecular structure.

The crystal structures of the two new ruthenium cluster anions, [crypt $222 \mathrm{~K}_{2}\left[\mathrm{Ru}_{4}(\mathrm{CO})_{13}\right]$ and [crypt $\left.22 \mathrm{I} \mathrm{Na}\right]_{2}$ $\left[\mathrm{H}_{2} \mathrm{Ru}_{4}(\mathrm{CO})_{12}\right]$ will be presented. By comparing the structures of $\mathrm{H}_{2} \mathrm{Ru}_{4}(\mathrm{CO})_{3}, \mathrm{HRu}_{4}(\mathrm{CO})_{13}^{-}$, and $\mathrm{Ru}_{4}(\mathrm{CO})^{2} \overline{3}$, it is of interest to note that the number of bridging carbonyls increases with increasing negative charge on the anion.

The crystal structures of five osmium-based bimetallic clusters, $\mathrm{H}_{3} \mathrm{PhRhO}_{3}(\mathrm{CO})_{9}, \mathrm{H}_{2} \mathrm{CpIrOs}_{3}(\mathrm{CO})_{10}, \mathrm{H}_{4} \mathrm{C}_{5} \mathrm{Me}_{5} \mathrm{RhOS}_{3}$ $(\mathrm{CO})_{9}, \mathrm{H}_{2}\left(\mathrm{C}_{5} \mathrm{He}_{5}\right)_{2} \mathrm{Rh}_{2} \mathrm{Os}_{2}(\mathrm{CO})_{7}$, and $\mathrm{H}_{2} \mathrm{CP}_{2} \mathrm{Rh}_{2} \mathrm{Os}_{2}(\mathrm{CO})_{7}$, will also be presented here. The molecular structures of these compounds exhibit the following properties: (i) molecules are based on a distorted tetrahedron, (ii) bridging carbonyls shorten the metal-metal distances, (iii) bridging hydrides elongate metal-metal bonds, and (iv) the ring ligands are displaced from their possible symmetrical aprical positions.
09. 5-4 PREPARATION AND X-RAY STRUCTURE DETERHINATION OF $\left[\mathrm{Li}_{6} \mathrm{Br}_{4}\left(E \mathrm{t}_{2} \mathrm{O}\right)_{10}\right]^{2}+\left[\mathrm{Ag}_{3} \mathrm{Li}_{2} \mathrm{Ph}_{6}\right]_{2}:$ Aiv UNUSUAL CATION COMPOSED OF A SOLVATED "SALT CLUSTER". By Robert. Bal, Michael Y. Chiang and Elmar Böhten, Department of Chemistry, University of Southern California, Los Angeles, CA 90089, U.S.A.

Following our recent report of the preparation and structure determination of the $\left[\mathrm{Cu}_{5}\left(\mathrm{C}_{6} \mathrm{H}_{5}\right)_{6}\right]^{-}$cluster, we have extended this chemistry into silver/pheny? complexes. The $\left[\mathrm{Ag}_{3} \mathrm{Li}_{2}\left(\mathrm{C}_{6} \mathrm{H}_{5}\right)_{6}\right]^{-}$mixed-metal cluster was prepared by treating a cold suspension $\left(0^{\circ} \mathrm{C}\right)$ of $\mathrm{AgBr}$ in diethyl ether with solution of freshly prepared phenyl lithium in a 1:3 molar ratio. After removal of half of the solvent, large colorless crystals of the title compound appeared upon standing (a few days of storage) at $-15^{\circ} \mathrm{C}$. $\left[\mathrm{Li}_{6} \mathrm{Br}_{4}\left(E t_{2} \mathrm{O}\right)_{10}\right]^{27}$ $\left[\mathrm{Ag}_{3} \mathrm{Li}_{2} \mathrm{Ph}_{6}\right]_{2}$ crystallizes in the monoclinic space group $P 2_{1} / \mathrm{n}$, with $a=16.497(12) \AA, b=29.790(20) \AA$, $c=12.792(7) \AA, \beta=100.19(5)^{\circ}, V=6187(7) \AA, Z=2$. The positions of the $\mathrm{Ag}$ and $\mathrm{Br}$ atoms were determined by direct methods (using the program MULTAN); and the coordinates of the rest of the atoms determined by standard heavy-atom techniques. Least-squares refinement resulted in a final $R$ factor of 0.076 for 4003 reflections with $\mathrm{I}>3 \sigma$ (I). The $\left[\mathrm{Ag} \mathrm{Li}_{2} \mathrm{Ph}_{6}\right]^{-}$ cluster (Figure 1) closely resembles the [Cu $\left.\mathrm{Ph}_{6}\right]^{-}$ cluster mentioned earlier, 1 having the same basic trigonal bipyramidal geometry with 1 ithium atoms in axiat positions. The $\left[\mathrm{Li}_{6} \mathrm{Br}_{4}\left(\mathrm{Et}_{2} \mathrm{O}\right)_{10}\right]^{2+} \mathrm{cation}$ is extremely unusual: it consists of a $\left[\mathrm{Li}_{6} \mathrm{Br}_{4}\right]^{2+}$ saltlike core surrounded by a shell of ten ether molecules. We thank the U.S. National Science Foundation (Grant CHE-81-01122) for support of this research.

_ _ . . . . . . . . . . . . . . . . .

1) P.G. Edwards, R.W. Gellert, M.H. Marks and R. Bau, J. Am. Chem. Soc., 104, 2072 (1982).

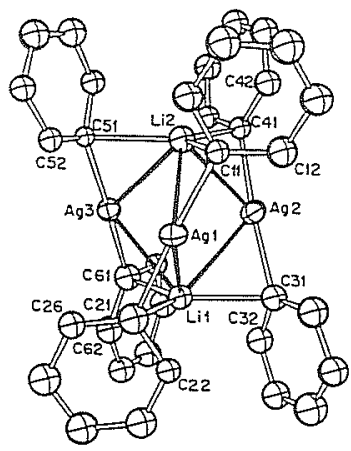

Figure 1: The $\left[\mathrm{Ag}_{3} \mathrm{Li}_{2}\left(\mathrm{C}_{6} \mathrm{H}_{5}\right)_{6}\right]^{-}$Anion

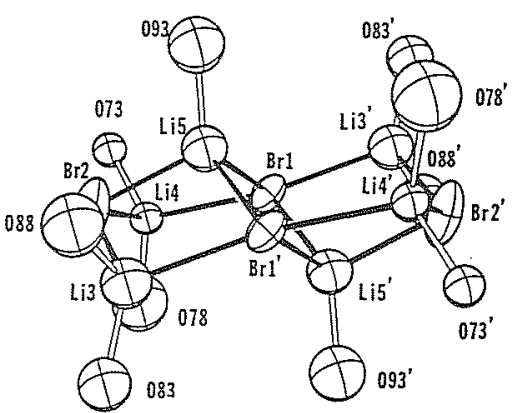

Figure 2: The $\left[\mathrm{Li}_{6} \mathrm{Br}_{4}\left(\mathrm{Et}_{2} \mathrm{O}\right)_{10}\right]^{2+}$ Cation 